\title{
The Effects of Antipsychotics on the Brain: What Have We Learnt from Structural Imaging of Schizophrenia? - A Systematic Review
}

\author{
R. Smieskova ${ }^{1,2}$, P. Fusar-Poli ${ }^{4}$, P. Allen ${ }^{3}$, K. Bendfeldt ${ }^{2}$, R.D. Stieglitz ${ }^{1}$, J. Drewe ${ }^{3}$, E.W. Radue ${ }^{2}$, \\ P.K. McGuire ${ }^{3}$, A. Riecher-Rössler ${ }^{1}$ and S.J. Borgwardt ${ }^{1,2,4, *}$
}

${ }^{1}$ Psychiatric Outpatient Department, ${ }^{2}$ Medical Image Analysis Centre, ${ }^{3}$ Dep. Clinical Pharmacology, University Hospital Basel, Petersgraben 4, CH-4031 Basel, Switzerland and ${ }^{4}$ Section of Neuroimaging, King's College London, Institute of Psychiatry, PO67, De Crespigny Park, London SE5 8AF, UK

\begin{abstract}
Despite a large number of neuroimaging studies in schizophrenia reporting subtle brain abnormalities, we do not know to what extent such abnormalities reflect the effects of antipsychotic treatment on brain structure. We therefore systematically reviewed cross-sectional and follow-up structural brain imaging studies of patients with schizophrenia treated with antipsychotics. 30 magnetic resonance imaging (MRI) studies were identified, 24 of them being longitudinal and six cross-sectional structural imaging studies. In patients with schizophrenia treated with antipsychotics, reduced gray matter volume was described, particularly in the frontal and temporal lobes. Structural neuroimaging studies indicate that treatment with typical as well as atypical antipsychotics may affect regional gray matter (GM) volume. In particular, typical antipsychotics led to increased gray matter volume of the basal ganglia, while atypical antipsychotics reversed this effect after switching. Atypical antipsychotics, however, seem to have no effect on basal ganglia structure.
\end{abstract}

Key Words: Schizophrenia, antipsychotics, typical, atypical neuroleptics, conventional, MRI, neuroimaging.

\section{INTRODUCTION}

Schizophrenia is a severe psychiatric disorder that affects about $1 \%$ of the population and is one of the top ten causes of disability worldwide [1]. Despite decades of research the neurobiological basis of schizophrenia is still largely unknown [2]. However, modern neuroimaging techniques have enabled us to examine the brains of patients with schizophrenia in vivo. A large body of neuroimaging studies have reported that as the illness proceeds, patients rapidly lose cerebral gray matter (GM), particularly in the frontal, temporal and limbic lobes $[3,4]$. The treatment of schizophrenia involves the use of antipsychotic drugs (typical antipsychotics, such as haloperidol), which act as antagonists at central dopamine $\mathrm{D}_{2}$ receptors $[5,6]$, although some of them have additional effects on other receptors [7]. A new generation of antipsychotic drugs, the atypical antipsychotics (for example quetiapine, olanzapine, risperidone and clozapine), with a lower affinity and occupancy for the dopaminergic receptors, but an additional occupancy for the serotoninergic $5-\mathrm{HT}_{2 \mathrm{~A}}$ and other receptors [8] have become available. Antipsychotics are effective in reducing the severity of positive psychotic symptoms but have limited impact on negative symptoms, cognitive impairment and produce a range of side effects including extra-pyramidal symptoms, prolactin elevation, sedation and cardio-metabolic effects [7]. Compared to typical antipsychotics, atypical antipsychotics induce less extra-pyramidal adverse effects and more metabolic adverse

\footnotetext{
*Address correspondence to this author at the Psychiatric Outpatient Department, Medical Image Analysis Centre, Petersgraben 4, CH-4031 Basel, Switzerland; Tel: 0041613286126; Fax: 0041612654588;

E-mail: sborgwardt@uhbs.ch
}

effects [7] but the underlying neurobiological mechanisms are still unclear.

One way to better understand these mechanisms is to use neuroimaging to investigate structural brain changes associated with a specific class of antipsychotic drugs. Neuroimaging is a potentially powerful tool to explore the impact of antipsychotic medication on brain structure in schizophrenia. Neuroimaging studies indicate that schizophrenia is associated with neuroanatomical abnormalities, with robust evidence of reduced GM volume in a number of cerebral regions $[9,10]$. In particular these studies demonstrated volumetric reductions in the whole brain, in the prefrontal cortex and in the superior and medial temporal lobes $[4,11$ 14]. These neuroimaging findings are also supported by post-mortem studies $[15,16]$.

Studies of schizophrenia and other psychiatric disorders have suggested that the ability of antipsychotic medication to induce anatomical and molecular changes in the brain may be relevant for its antipsychotic properties in addition to their action on neurotransmission [17-21]. However, despite considerable research, a major concern for neuroimaging studies of patients with schizophrenia is the potential confound of antipsychotic medication. Thus, it remains unclear to what extent structural changes are due to the ongoing illness process and to what extent to medication and how different antipsychotic medications affect neuroimaging measures. The aim of this article is to systematically review neuroimaging studies addressing the impact of antipsychotic medication on brain structure. In addition, we examine the different effects of typical and atypical antipsychotic medication. 


\section{METHODS}

\section{Selection Procedures}

\section{Search Strategy}

Electronic searches were performed using PUBMED database on antipsychotic medication and neuroimaging. Since our main focus was to examine potential different medication effects of typical and atypical antipsychotics on neuroimaging measures, we included all existing structural neuroimaging studies of adult and childhood-onset schizophrenia published until November 2008, without any language restriction. Patients met diagnostic criteria for schizophrenia or schizophreniform or schizoaffective disorder according to Diagnostic and Statistical Manual of Mental Disorders DSM-III-R or DSM-IV criteria. The search terms were: schizophrenia, antipsychotic medication, typical antipsychotic, atypical antipsychotic, conventional antipsychotic, basal ganglia, ventricular enlargement, caudate, cortical gray, white matter (WM), morphometry, brain imaging, neuroimaging, magnetic resonance imaging, and MRI.

\section{Selection Criteria}

First, studies that investigated brain structure and differences between groups of patients treated with typical or atypical antipsychotics were included. We hand-searched all the publications in order to find longitudinal and cross-sectional neuroimaging studies considering the effects of antipsychotic medication as well as the references of all manuscripts for further relevant publications. To qualify for inclusion in this review the studies must have: (a) been an original publication in a peer-reviewed journal (b) studying schizophrenic patients using neuroimaging techniques according to antipsychotic medication (c) considering the differences in medication either among various antipsychotic medications or over the time among various groups of patients.

According to their clinical stage, patients with schizophrenia were considered as patients with a first episode (defined as first hospitalization [22], less than five years` total duration of disease [23]), recent onset (first hospitalization within the last 5 years [22]), chronic patients (disease duration greater than five years [24], disease duration more than ten years [23]), or therapy resistant chronic patients (chronic and refractory to conventional treatment [25]). We used the term antipsychotic-naïve for those patients who have never used any antipsychotic medication and 'antipsychotic-free' for patients free of antipsychotic medication for at least two months before admission [26].

\section{Recorded Variables}

One approach for systematic reviews is to survey the literature and then provide an informed interpretation of the main findings. However, with this approach the review's summarising process may be opaque to the reader, who cannot assess the validity of the conclusions without reading the original papers. In the present review we have tried to help the readers to form their own opinion by presenting a number of key quantitative measures from the studies reviewed in informative tables. Two of the authors extracted the data independently (SB and RS). The recorded variables for articles used in the review were: type of medication, mean dose of the used drugs, chlorpromazine equivalents, regional volumetric brain differences, type of study design (longitudinal/cross-sectional) and imaging analysis method (regionof-interest, voxel-based morphometry) and the demographic characteristics of patients groups.

\section{RESULTS}

In recent years a large number of neuroimaging studies have been conducted to evaluate the variations and longitudinal changes in brain structure in various groups of patients, often reporting contradictory results. 30 studies published between 1996 and 2008 met the inclusion criteria and were reviewed, 24 of them being longitudinal and six crosssectional structural imaging studies. Table $\mathbf{1}$ contains an overview of all reviewed studies for better orientation.

\section{Structural Neuroimaging Studies}

We reviewed structural MRI studies evaluating GM volume differences between patients and healthy controls (cross-sectional) as well as progressive changes (longitudinal) in whole and regional brain volumes and compared these between groups of patients according to their antipsychotic treatment.

\section{Cross-Sectional MRI Studies}

In total, six cross-sectional MRI studies were reviewed. Two cross-sectional studies compared patients treated with typical antipsychotics only to healthy controls [22, 24] and four studies compared patients treated with different antipsychotics [3, 23, 27].

The results of Kopelman et al. suggest that patients treated with typical antipsychotics have a thicker cortical depth of the left anterior cingulate gyrus without displaying any difference in surface area compared to healthy controls [24]. In another study increasing exposure to typical antipsychotics correlated with a larger insular volume, but the differences between patients and healthy controls were not significant [22].

Brain structural changes associated with the use of typical or atypical antipsychotics in first-episode psychosis patients are mostly qualitative, because they appear as significant in each group compared only to the drug-free group. Treatment with typical antipsychotics was associated with an enlargement of the basal ganglia and size reductions in insula, extending into inferior frontal and superior temporal gyrus, in lobulus paracentralis, anterior cingulate gyrus and precuneus [27]. However, treatment with atypical antipsychotics was associated solely with an enlargement of the thalami [27]. Pituitary volume was $30 \%$ larger in the firstepisode patients receiving typical antipsychotics and $17 \%$ larger in patients receiving atypical antipsychotics compared to healthy controls [28]. Higher doses of a typical antipsychotic were associated with larger caudate, putamen and thalamus volumes, whereas a higher dose of an atypical antipsychotic only with larger thalamic volume [3]. Firstepisode schizophrenic patients treated with atypical antipsychotics had larger hippocampal volumes than those treated with typical antipsychotics [23]. The specifics of each of these cross-sectional MRI studies have been included in Table 2. 
Table 1. Overview of Reviewed Studies

\begin{tabular}{|c|c|c|c|c|c|c|c|c|c|}
\hline \multirow{3}{*}{$\begin{array}{c}\text { Study } \\
\text { (Reference) }\end{array}$} & \multicolumn{4}{|c|}{ Population } & \multirow{3}{*}{$\begin{array}{l}\text { Specification of } \\
\text { Study Design }\end{array}$} & & \multirow{3}{*}{$\begin{array}{l}\text { CPZ E } \\
\mathrm{mg} / \mathrm{d}\end{array}$} & & \multirow{3}{*}{$\begin{array}{l}\text { CPZ E } \\
\mathrm{mg} / \mathrm{d}\end{array}$} \\
\hline & & \multicolumn{3}{|c|}{ Patients } & & & & & \\
\hline & $\mathbf{C}$ & Typical & Atypical & $\mathbf{A F} / \mathbf{A} \mathbf{N}$ & & $\begin{array}{c}\text { Typicals, n of Subjects, } \\
\text { Mean Dose }\end{array}$ & & $\begin{array}{c}\text { Atypicals, n of Subjects, } \\
\text { Mean Dose }\end{array}$ & \\
\hline $\begin{array}{l}\text { Chakos et al. - } \\
2004 \text { [42] }\end{array}$ & 10 & $8 \mathrm{FE}$ & & $21 \mathrm{AN}$ & $\begin{array}{l}\text { standardized neuroleptic } \\
\text { regimens fewer than } 12 \\
\text { weeks or none (enter of the } \\
\text { study) }\end{array}$ & $\begin{array}{l}\text { up to } 3 \text { diff. neuroleptics } \\
\text { (n of subjects n/a) }\end{array}$ & $400-900$ & $\begin{array}{l}\text { up to } 3 \text { diff. neuroleptics } \\
\text { (n of subjects n/a) }\end{array}$ & $400-900$ \\
\hline $\begin{array}{l}\text { Chakos et al. - } \\
2005[23]\end{array}$ & 26 & $\begin{array}{c}22 \text { (17 FE, } 5 \\
\text { ChP })\end{array}$ & $\begin{array}{c}32(15 \mathrm{FE} \\
17 \mathrm{ChP})\end{array}$ & - & $\begin{array}{c}\text { FE: } 17 \text { haloperidol, } 15 \\
\text { atypicals = } 12 \text { olanzapine, } 3 \\
\text { risperidone, } 1 \text { clozap- } \\
\text { ine+molindone, } 1 \text { unknown; } \\
\text { Ch P: } 5 \text { typicals = } 3 \text { halop- } \\
\text { eridol, } 1 \text { trifluoroperzine, } 1 \\
\text { thiothixene, } 17 \text { atypicals }=6 \\
\text { olanzapine, } 8 \text { clozapine, } 3 \\
\text { risperidone }\end{array}$ & $\begin{array}{c}17 \text { haloperidol, } 1 \text { clozap- } \\
\text { ine+molindone, Ch P: } 5 \\
\text { typicals = } 3 \text { haloperidol, } 1 \\
\text { trifluoroperzine, } 1 \text { thiothix- } \\
\text { ene }\end{array}$ & $\mathrm{n} / \mathrm{a}$ & $\begin{array}{c}12 \text { olanzapine, } 3 \text { risperidone, } 1 \\
\text { clozapine+molindone; } 6 \\
\text { olanzapine, } 8 \text { clozapine, } 3 \\
\text { risperidone }\end{array}$ & $\mathrm{n} / \mathrm{a}$ \\
\hline $\begin{array}{c}\text { Christensen } \\
\text { et al. - } 2004 \text { [30] }\end{array}$ & 8 & $16 \mathrm{FE}$ & & - & $\begin{array}{c}\text { AF baseline } \bar{A} 4 \text { week } \\
\text { continued hospitalization: } 4 \\
\text { mg risperidone, } 7 \mathrm{mg} \\
\text { haloperidol, } 120 \mathrm{mg} \text { zipra- } \\
\text { sidone }\end{array}$ & haloperidol (7 mg) & 350 & $\begin{array}{l}\text { risperidone }(4 \mathrm{mg}) \text {, ziprasi- } \\
\text { done }(120 \mathrm{mg})\end{array}$ & $200 ; 200$ \\
\hline $\begin{array}{l}\text { Chua et al. - } \\
2008[31]\end{array}$ & - & $15 \mathrm{FE}$ & $5 \mathrm{FE}$ & $25 \mathrm{AN}$ & - & $\begin{array}{l}13 \text { haloperidol, } 1 \text { trifluor- } \\
\text { perazine, } 1 \text { sulpirid }\end{array}$ & 318 & 5 amisulpirid & 318 \\
\hline $\begin{array}{l}\text { Corson et al. - } \\
1999 \text { [46] }\end{array}$ & - & $\begin{array}{l}13 \mathrm{FE} \\
(5 \text { typ }+ \\
\text { atyp. })\end{array}$ & $\begin{array}{c}10 \mathrm{FE} \\
(4 \text { type }+ \\
\text { typ. })\end{array}$ & - & $\begin{array}{l}\text { time of intake: } 4 \mathrm{AN}, 14 \\
\text { typ., } 5 \text { typ. }+ \text { atyp.; }\end{array}$ & $\begin{array}{l}\text { haloperidol, trifluoperazine, } \\
\text { thiothixene, fluphenazine, } \\
\text { thioridazine, perphenazine, } \\
\text { chlorpromazine ( } \mathrm{n} \text { of } \\
\text { subjects } \mathrm{n} / \mathrm{a} \text { ) }\end{array}$ & $\mathrm{n} / \mathrm{a}$ & $\begin{array}{l}\text { clozapine, risperidone, olan- } \\
\text { zapine ( } \mathrm{n} \text { of subjects n/a) }\end{array}$ & $\mathrm{n} / \mathrm{a}$ \\
\hline $\begin{array}{l}\text { Dazzan et al. - } \\
2005 \text { [27] }\end{array}$ & - & $32 \mathrm{FE}$ & $30 \mathrm{FE}$ & $\begin{array}{l}13 \mathrm{AN} \\
+9 \mathrm{AF}\end{array}$ & $\begin{array}{l}\text { cross-sectional non- } \\
\text { randomized, VBM }\end{array}$ & $\begin{array}{l}\text { chlorpromazine, sulpiride, } \\
\text { haloperidol, thioridazine, } \\
\text { droperidol, trifluoperazine, } \\
\text { zuclopenthixol (n of sub- } \\
\text { jects n/a) }\end{array}$ & $269.5 \pm 245$ & $\begin{array}{l}21 \text { olanzapine }(14 \mathrm{mg}), 5 \\
\text { risperidone }(4 \mathrm{mg}), 2 \text { quetiap- } \\
\text { ine }(400 \mathrm{mg}), 1 \text { sertindole } \\
(16 \mathrm{mg}), 1 \mathrm{amisulpiride} \\
(400 \mathrm{mg})\end{array}$ & $\begin{array}{l}280 ; 200 ; \\
\quad 533 ; \\
\text { sertindole } \\
\text { n/a; } 400\end{array}$ \\
\hline $\begin{array}{l}\text { Frazier et al. - } \\
\qquad 1996[38]\end{array}$ & 8 & - & 8 & - & 2 years & 1 haloperidol (1mg/d) & 50 & 8 clozapine $(400 \mathrm{mg} / \mathrm{d})$ & 800 \\
\hline $\begin{array}{l}\text { Garver et al. - } \\
2005 \text { [26] }\end{array}$ & 7 & $6(3 \mathrm{FE})$ & $13(7 \mathrm{FE})$ & - & $\begin{array}{c}\text { scan before and after } 28 \\
\text { days of treatment }\end{array}$ & 6 haloperidol $(7 \mathrm{mg} / \mathrm{d})$ & 350 & $\begin{array}{l}7 \text { risperidone }(4 \mathrm{mg} / \mathrm{d}) \text { and } 6 \\
\text { ziprasidone }(120 \mathrm{mg} / \mathrm{d})\end{array}$ & $\begin{array}{l}200 \text { and } \\
200\end{array}$ \\
\hline $\begin{array}{l}\text { Girgis et al. - } \\
2006[35]\end{array}$ & 15 & - & $15 \mathrm{AN}$ & - & 6 week follow-up & - & - & 15 risperidone $2,67 \pm 1.23 \mathrm{mg}$ & 133 \\
\hline $\begin{array}{l}\text { Gogtay et al. - } \\
2004 \text { [37] }\end{array}$ & 38 & - & $23 \mathrm{COS}$ & - & $\begin{array}{l}\text { baseline: } 22 \text { medication (17 } \\
\text { typ. and } 5 \text { atyp.) } \bar{A} \text { follow } \\
\text { up } 23 \text { atyp.:during study } \\
\text { most recived atyp. }\end{array}$ & $\begin{array}{l}\text { baseline } 17 \text { typ. (n of } \\
\text { subjects } \mathrm{n} / \mathrm{a} \text { ) }\end{array}$ & - & $\begin{array}{c}\text { baseline: } 5 \text { atyp., folow-up: } 23 \\
\text { atyp. (15 clozapine) }\end{array}$ & $\mathrm{n} / \mathrm{a}$ \\
\hline $\begin{array}{c}\text { Gur et al. - } \\
1998[3]\end{array}$ & 128 & $\begin{array}{l}48 \text { PT ChP - } \\
\text { only typ. }\end{array}$ & $\begin{array}{c}27 \mathrm{PT} \\
\text { ChP typ. }+ \\
\text { atyp. }\end{array}$ & $21 \mathrm{AN}$ & - & $\begin{array}{c}48 \text { typ. ( } 28 \text { haloperidol, } 8 \\
\text { haloperidol dekanoat, } 6 \\
\text { loxapine, } 8 \text { thioridazine, } 3 \\
\text { molindone, } 12 \text { thiothixene, } \\
4 \text { fluphenazine, } 4 \\
\text { fluphenazine decanoat, } 9 \\
\text { trifluoperazine, } 7 \text { per- } \\
\text { phenazine, } 8 \text { chlorpromaz- } \\
\text { ine), } 22 \text { typ. }+ \text { atyp. }(15 \\
\text { clozapine, } 16 \text { risperidone) }\end{array}$ & 407.1 & $\begin{array}{c}22 \text { typ. + atyp. (15 clozapine, } \\
16 \text { risperidone), } 5 \text { only risperi- } \\
\text { done }\end{array}$ & $\begin{array}{c}58.2- \\
3723.5 \\
150-400 \\
286.3\end{array}$ \\
\hline
\end{tabular}


(Table 1) contd....

\begin{tabular}{|c|c|c|c|c|c|c|c|c|c|}
\hline \multirow{3}{*}{$\begin{array}{c}\text { Study } \\
\text { (Reference) }\end{array}$} & \multicolumn{4}{|c|}{ Population } & \multirow{3}{*}{$\begin{array}{l}\text { Specification of } \\
\text { Study Design }\end{array}$} & & \multirow{3}{*}{$\begin{array}{l}\text { CPZ E } \\
\mathrm{mg} / \mathrm{d}\end{array}$} & & \multirow{3}{*}{$\begin{array}{l}\text { CPZ E } \\
\mathrm{mg} / \mathrm{d}\end{array}$} \\
\hline & \multicolumn{4}{|c|}{ Patients } & & & & & \\
\hline & $\mathbf{C}$ & Typical & Atypical & AF/AN & & $\begin{array}{l}\text { Typicals, n of Subjects, } \\
\text { Mean Dose }\end{array}$ & & $\begin{array}{c}\text { Atypicals, n of Subjects, } \\
\text { Mean Dose }\end{array}$ & \\
\hline $\begin{array}{l}\text { Heitmiller et al.- } \\
\quad 2004 \text { [43] }\end{array}$ & 14 & & $14 \mathrm{AN} \mathrm{FE}$ & & only atyp. & - & - & $\begin{array}{l}7 \text { males: } 2 \text { risperidone, } 1 \\
\text { olanzapine later quetiapine, } 3 \\
\text { risperidone and/or olanzapine, } \\
1 \text { risperidone olanzapine } \\
\text { finally clozapine; } 7 \text { females: } 2 \\
\text { risperidone, } 1 \text { risperidone and } \\
\text { /or quetiapine, } 1 \text { olanzapine, } 3 \\
\text { risperidone and/or olanzapine }\end{array}$ & $\mathrm{n} / \mathrm{a}$ \\
\hline $\begin{array}{l}\text { Ho et al. - } \\
2003 \text { [49] }\end{array}$ & 23 & $40 \mathrm{RO}$ & - & $33 \mathrm{AN}$ & naturalistic study & 7 typ., 11 typ. + atyp. & 462.2 & $\begin{array}{c}20 \text { atyp. (olanzapine, quetiap- } \\
\text { ine, risperidone, ziprasidone), } \\
15 \text { clozapine }\end{array}$ & 462.2 \\
\hline $\begin{array}{c}\text { James et al. - } \\
2004[39]\end{array}$ & 16 & - & $16 \mathrm{COS}$ & - & - & - & - & 16 atyp., 3 also clozapine & 279 \\
\hline $\begin{array}{c}\text { Kopelman et al.- } \\
2005[24]\end{array}$ & 30 & $\begin{array}{c}30(6 \mathrm{FE}, 11 \\
\mathrm{RO}, 13 \\
\mathrm{ChP})\end{array}$ & - & - & only males & $\begin{array}{l}\text { only typicals (n of subjects } \\
\text { n/a) }\end{array}$ & \begin{tabular}{|}
$\mathrm{CPZ}$ \\
equvalents \\
from 0.5 \\
to 650 \\
"dose- \\
year"
\end{tabular} & - & - \\
\hline $\begin{array}{l}\text { Lang et al.- } \\
2004[44]\end{array}$ & 23 & $10 \mathrm{ChP}$ & 37 & - & $\begin{array}{l}\text { baseline typ. (10) or risperi- } \\
\text { done (13) - limited response } \\
\text { switched to olanzapine, } 14 \\
\text { patients receiving risperi- } \\
\text { done - good response - } \\
\text { continued }\end{array}$ & $\begin{array}{l}\text { baseline (10): loxapine, } \\
\text { trifluoperazine, chlorpro- } \\
\text { mazine, fluphenazine, } \\
\text { haloperidol switched to } \\
\text { olanzapine }\end{array}$ & 360.1 & $\begin{array}{c}\text { baseline: } 13 \text { risperidone } \\
\text { switched to olanzapine, } 14 \\
\text { patients receiving risperidone - } \\
\text { good response - continued }\end{array}$ & $\begin{array}{c}\text { olanzapine } \\
\text { switched } \\
\text { from } \\
\text { typicals } \\
170.0+ \\
\text { switched } \\
\text { from } \\
\text { risperidone } \\
150.0 ; \\
\text { risperidone } \\
84.0\end{array}$ \\
\hline $\begin{array}{l}\text { Lieberman et al.- } \\
\quad 2005[32]\end{array}$ & 58 & $82 \mathrm{FE}$ & $82 \mathrm{FE}$ & - & $\begin{array}{l}\text { double blind randomized } \\
\text { week } 0,12,24,52,104\end{array}$ & 82 haloperidol (2-20mg/d) & $100-1000$ & 82 olanzapine $(5-20 \mathrm{mg} / \mathrm{d})$ & $100-400$ \\
\hline $\begin{array}{c}\text { Massana et al. - } \\
2005[36]\end{array}$ & - & - & $11 \mathrm{AN}$ & - & $\begin{array}{c}\text { baseline: AN } \bar{A} 3 \text { months } \\
\text { risperidone }\end{array}$ & - & - & $\begin{array}{l}14 \text { risperidone, mean dose } \\
6.05 \mathrm{mg} / \mathrm{d}\end{array}$ & 302.5 \\
\hline $\begin{array}{l}\text { McClure et al.- } \\
2006[29]\end{array}$ & - & $\begin{array}{l}2 \text { stabile } \\
\mathrm{ChP}\end{array}$ & $\begin{array}{l}6 \text { stabile } \\
\mathrm{ChP}\end{array}$ & - & $\begin{array}{c}2 \text { scans within } 4-8 \text { weeks } 8 \\
\text { ChP stable treatment }\end{array}$ & $\begin{array}{c}1 \text { thiothixene }(10 \mathrm{mg} / \mathrm{d}), 2 \\
\text { perphenazine }(8 \mathrm{mg} / \mathrm{d})\end{array}$ & $200 ; 800$ & $\begin{array}{c}1 \text { clozapine }(800 \mathrm{mg} / \mathrm{d}), 1 \\
\text { quetiapine }(200 \mathrm{mg} / \mathrm{d})+ \\
\text { risperiodne }(4 \mathrm{mg} / \mathrm{d}), 1 \text { olan- } \\
\text { zapine }(30 \mathrm{mg} / \mathrm{d}), 1 \text { olanzapine } \\
(5 \mathrm{mg} / \mathrm{d}), 1 \text { olanzapine } \\
(20 \mathrm{mg} / \mathrm{d}), 1 \text { risperiodne } \\
(9 \mathrm{mg} / \mathrm{d})+\text { quetiapine } \\
(400 \mathrm{mg} / \mathrm{d})\end{array}$ & $\begin{array}{c}1600 ; 267 \\
200 \\
600 ; 100 \\
400 ; 450 \\
533.3\end{array}$ \\
\hline $\begin{array}{l}\text { McClure et al. } \\
2008[33]\end{array}$ & - & - & $10 \mathrm{ChP}$ & - & $\begin{array}{c}\text { off medication } 39.4 \text { days, } \\
\text { then brief period ( } 12 \text { weeks) } \\
\text { atypicals }\end{array}$ & - & - & $\begin{array}{l}\text { olanzapine }(10-20 \mathrm{mg} / \mathrm{day}) \\
\text { risperidone }(4-6 \mathrm{mg} / \mathrm{day}) \\
\text { quetiapine }(300-800 \mathrm{mg} / \text { day }) \\
\text { clozapine }(500-1000 \mathrm{mg} / \text { day) } \\
\quad(\mathrm{n} \text { of subjects } \mathrm{n} / \mathrm{a})\end{array}$ & $\begin{array}{c}200-400 \\
200- \\
300 ; 400- \\
1067 ; 1000- \\
2000\end{array}$ \\
\hline $\begin{array}{c}\text { McCormick et al. } \\
2005[48]\end{array}$ & 18 & $9 \mathrm{AN}$ & $22 \mathrm{AN}$ & - & - & $\begin{array}{c}5 \text { haloperidol, } 2 \text { per- } \\
\text { phenazine, } 1 \text { fluphenazine, } \\
1 \text { thiothixene ( } 8 \text { pure, } 1 \\
\text { mixed) }\end{array}$ & dose years & $\begin{array}{l}10 \text { risperidone, } 11 \text { olanzapine, } \\
1 \text { clozapine ( } 15 \text { pure, } 7 \text { mixed })\end{array}$ & dose years \\
\hline
\end{tabular}


(Table 1) contd....

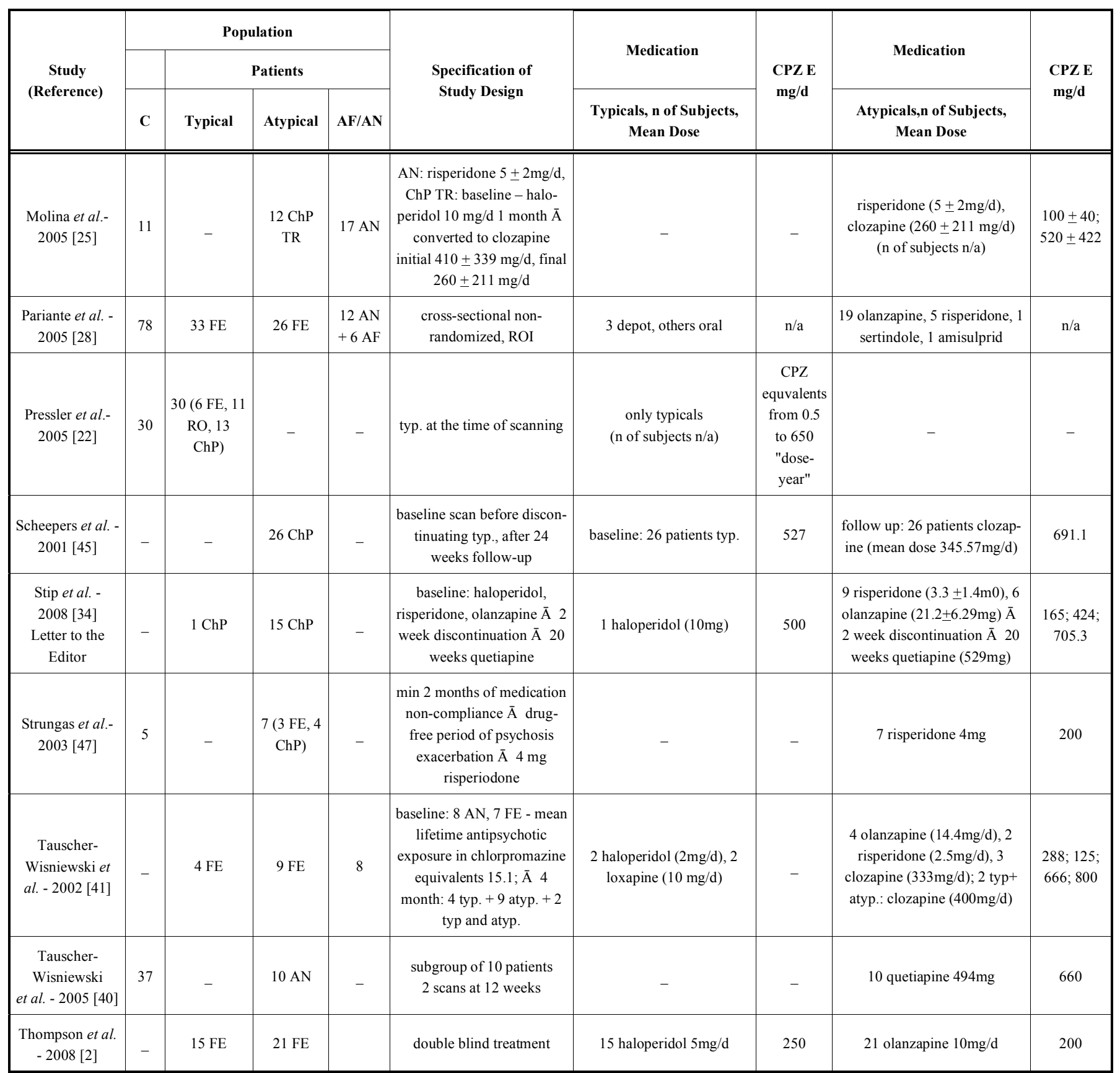

All studies are also referenced in the text. Abbreviations $\mathrm{C}=$ control; $\mathrm{AN}=$ antipsychotic-naïve; $\mathrm{AF}=$ antipsychotic free; $\mathrm{PT}=$ previously treated; $\mathrm{FE}=$ first episode; $\mathrm{RO}=$ recent onset; $\mathrm{TR}=$ treatment resistant; $\mathrm{ChP}=$ chronic patient; $\mathrm{BG}=$ basal ganglia; $\mathrm{CPZ}=$ chlorpromazine; $\mathrm{CPZ} \mathrm{E}=$ chlorpromazine equivalent; $\mathrm{VBM}=$ voxel-based morphometry; $\mathrm{ROI}=$ region of interest; $\mathrm{BT}=$ before therapy; $\mathrm{AT}=$ after therapy; $\mathrm{GM}=$ gray matter.

\section{Longitudinal MRI Studies Using Voxel-Based Morphome- $\operatorname{try}(V B M)$}

In total, 13 longitudinal MRI studies using VBM methods were reviewed. Two studies of patients treated with typical and atypical antipsychotics did not examine the differences between subgroups of antipsychotic medication [29, 30]. Another four longitudinal studies searched for progressive changes after treatment with either of atypical antipsychotics $[2,26,31,32]$. Seven studies evaluated the changes in brain structure after medication with only atypical antipsychotic medication [33-39]. Three studies assessed chronic patients with schizophrenia [29, 33, 34], two studies focused on childhood-onset psychosis $[38,39]$, whereas the other studies only included patients with first-episode schizophrenia $[2,26,30-32,35-37]$. The brain changes were compared with a healthy control group comprising healthy volunteers in seven studies [26, 30, 32, 35, 37-39].

A study that examined the effects of medication with typical antipsychotics revealed GM increases in basal ganglia volume [32], whereas the basal ganglia volume remained unchanged following treatment with atypical antipsychotics [34]. 
Table 2. Cross-Sectional MRI Studies of Patients with Schizophrenia

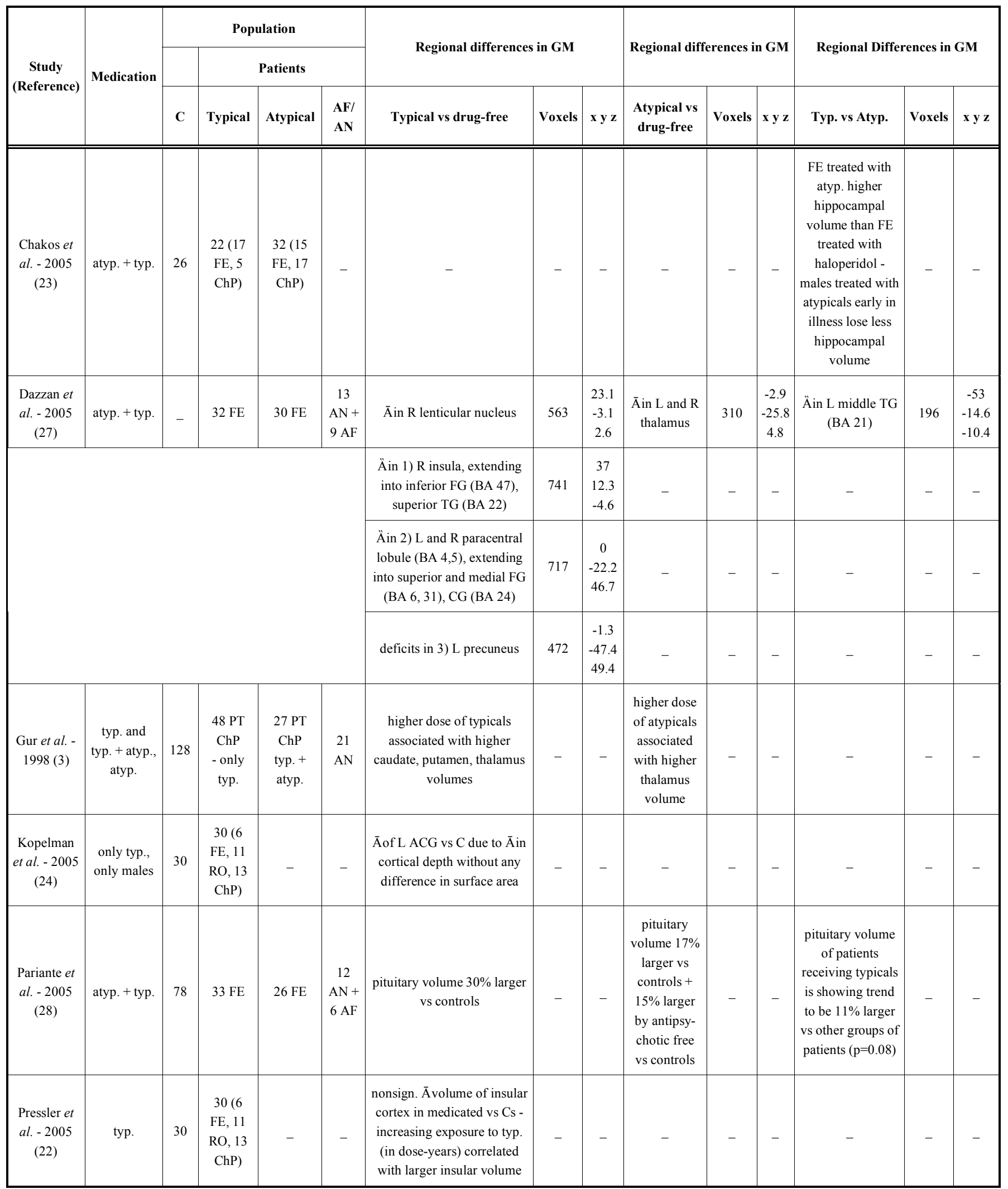

All studies are also referenced in the text. Abbreviations $\mathrm{x}$ y $\mathrm{z}=$ Talairach coordinates; $\mathrm{C}=$ control; $\mathrm{AN}=$ antipsychotic naïve; $\mathrm{AF}=$ antipsychotic free; $\mathrm{PT}=$ previously treated; $\mathrm{FE}=$ first episode; $\mathrm{RO}=$ recent onset; $\mathrm{TR}=$ chronic resistant; $\mathrm{ChP}=$ chronic patient; $\mathrm{BG}=$ basal ganglia; $\overline{\mathrm{A}}=$ excess, increase, higher; $\mathrm{A}=$ decrease, deficit; $\mathrm{R}=$ right; $\mathrm{L}=$ left; $\mathrm{TG}=$ temporal gyrus; $\mathrm{FG}=$ frontal gyrus; $\mathrm{CG}=$ cingulate gyrus; $\mathrm{BA}=$ Brodmann area; typ. = typical antipsychotics; atyp. = atypical antipsychotics 
The study by Lieberman et al. [32] is the only controlled, double blind, randomized, multi-site longitudinal study. With a relatively large sample size of seventy-nine patients with first-episode schizophrenia, patients treated with haloperidol showed significant reductions in GM volume compared to healthy controls. In contrast, olanzapine-treated patients did not show any significant decreases in GM volume during the follow up period. GM reduction in the haloperidol group was evident during the first 12 weeks in frontal GM and at week 52 in the temporal and parietal GM. Significant volume increases in the caudate nucleus in the haloperidol group were observed at weeks 24, 52 and 104 compared to olanzapine group [32].

In another study by Thompson et al. the dynamics of illness progression in treated patients were shown for typical versus atypical antipsychotic drugs [2]. The haloperidoltreated group showed the fastest tissue loss in the frontal cortex during the first year of psychosis. In the olanzapine group the brain changes occurred more posteriorly in occipital and limbic regions. These results suggest that antipsychotic medication may not be entirely protective. The volumetric changes related to antipsychotic medication are regionally much more pronounced than it would be predicted from healthy controls. However, the differences between the medication groups were less pronounced after a 12-month period [2].

Among a small sample of patients with chronic schizophrenia, relative volume increases in left hippocampal GM were found in patients treated with atypical, but not with typical antipsychotics [29]. Patients treated with typical antipsychotics showed a trend towards decreasing total cerebrospinal fluid (CSF) volume [29]. In medication-free chronic patients treated briefly with atypical antipsychotics no significant changes in GM volume were observed [33]. Results from another study of patients with chronic schizophrenia showed greater GM density in the basal ganglia after 20 weeks of medication with quetiapine [34]. These findings were contradictory to previous short-term follow up studies $[26,29,33]$.

Individuals with first-episode psychosis, who received short-term treatment (six weeks) with risperidone, showed increased GM volume in the temporal cortex and decreased GM in frontal cortex. Risperidone-treatment was associated with reduced WM and was found in the corpus callosum, cerebellum and right anterior cingulate [35].

In childhood-onset schizophrenia clozapine treated patients had larger caudate volume compared to healthy controls [38]. However, after two years of clozapine treatment, caudate volume did not differ between baseline and followup scan [38]. In adolescent-onset schizophrenia, smaller volumes in the prefrontal cortex and thalamus, a larger fourth ventricle volume and a reduced cerebellar (i.e. vermis) volume were found in a longitudinal study with patients treated with atypical antipsychotics [39].

Relative to antipsychotic-naïve patients, patients receiving treatment (15 with typical, five with atypical antipsychotics) had relatively greater GM volumes in the caudate and in the cingulate gyri extending to the left medial frontal gyrus [31] after three-four weeks of treatment. Results from recently decompensated antipsychotic-free schizophrenic patients showed no evidence, that a four-week antipsychotic treatment itself may cause volumetric change in cerebral WM volume [30]. Patients with childhood-onset schizophrenia treated for two years with atypical antipsychotics showed GM reductions in parietal and fronto-temporal cortices as well as reduced total GM volume [37]. The specifics of each of these longitudinal VBM studies have been included in Table 3.

\section{Longitudinal Studies Using a Region-of-Interest (ROI) Approach}

In total, 11 longitudinal MRI studies using ROI methods were reviewed. Seven longitudinal studies using an ROI approach focused on basal ganglia [40-46], one on the thalamus [47], one on the anterior cingulate gyrus [48] and two studies on other cortical regions $[25,49]$. Five studies evaluated GM changes after treatment with atypical antipsychotic medication only [25, 40, 43, 45, 47], four compared typical versus atypical antipsychotic $[41,44,46,48]$ and two did not examine for the differences between these two subtypes of antipsychotic drugs $[42,49]$.

No differences between baseline and follow-up in caudate volumes were seen in a subgroup of ten patients after 12 weeks of quetiapine treatment [40]. After a five-year followup only an age-related decline in caudate volume in patients' treatment with both typical and atypical antipsychotics and healthy controls was found [41]. At the beginning the antipsychotic-naïve patients treated exclusively with atypical antipsychotics showed only a negligible volume enlargement of the caudate after two years, but these changes may be sexdependent [43]. Female patients with a greater amount of drug exposure had fewer enlargements of caudate nuclei. In males the correlation was reversed [43]. Treatment with typical antipsychotics was associated with larger basal ganglia volumes and switching to olanzapine was associated with a reduction in basal ganglia volumes [44]. Volumes of putamen and globus pallidus were normalized following the switch to olanzapine. In the group of risperidone-treated patients, who later switched to olanzapine, no significant differences in overall basal ganglia volume were seen [44]. Treatment with clozapine in schizophrenic patients previously treated with typical antipsychotics resulted in decreased caudate volume [45]. Volume of caudate and nucleus lentiformis increased after exposure to typical antipsychotics and decreased following exposure to atypical antipsychotics [46]. Caudate volumes increased in first-episode patients during 18 -month treatment by $5.7 \%$ and decreased by $1.6 \%$ in healthy controls [42].

Several other longitudinal studies in chronic and first episode treated with both typical and atypical medication have produced evidence for GM volume changes in different regions including the parietal and occipital lobes [25] and thalamic volume [49]. Exposure to typical antipsychotics was associated with an increase in anterior cingulate cortex (ACC) volume over time while exposure to the atypical class of antipsychotics was associated with a decrease in volume of ACC over time [48]. Progressive brain changes in patients with schizophrenia occur despite ongoing antipsychotic drug-treatment, however, no significant differences were 
Table 3. Longitudinal MRI Studies of Patients with Schizophrenia

\begin{tabular}{|c|c|c|c|c|c|c|c|c|c|c|c|c|c|}
\hline \multirow{3}{*}{ ڤ્气 } & \multirow{3}{*}{ 冚 } & \multirow{3}{*}{$\begin{array}{l}\text { Medi- } \\
\text { cation }\end{array}$} & \multicolumn{4}{|c|}{ Population } & \multirow{2}{*}{\multicolumn{3}{|c|}{ Regional Differences in GM }} & \multirow{2}{*}{\multicolumn{3}{|c|}{ Regional Differences in GM }} & \multirow{3}{*}{$\begin{array}{c}\text { Regional Differ- } \\
\text { ences in GM } \\
\text { Typical vs Atypical }\end{array}$} \\
\hline & & & \multirow{2}{*}{$\mathbf{C}$} & \multicolumn{3}{|c|}{ Patients } & & & & & & & \\
\hline & & & & Typical & Atypical & AF/AN & $\begin{array}{l}\text { Typical vs } \\
\text { Drug-Free }\end{array}$ & $\begin{array}{l}\text { Num. of } \\
\text { Voxels }\end{array}$ & $\mathbf{x} \mathbf{y} z$ & $\begin{array}{l}\text { Atypical vs } \\
\text { Drug-Free }\end{array}$ & $\begin{array}{c}\text { Num. of } \\
\text { Voxels }\end{array}$ & $\mathbf{x} \mathbf{y} \mathbf{z}$ & \\
\hline \multirow{7}{*}{ 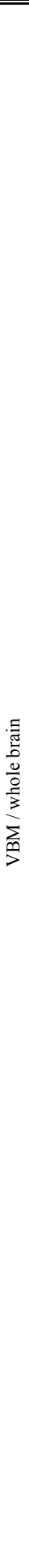 } & 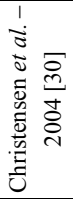 & $\begin{array}{l}\text { typ. }+ \\
\text { atyp }\end{array}$ & 8 & \multicolumn{2}{|c|}{16} & - & \multicolumn{5}{|c|}{$\begin{array}{l}\text { responders of treatment ( } 13 \text { patients - of SAPS) - of WMV, } 3 \\
\text { drug-nonresponders - nonsign. A Aof WMV; no evidence, that antipsychotic } \\
\text { treatment itself caused volumetric change in cerebral WMV }\end{array}$} & - & - \\
\hline & 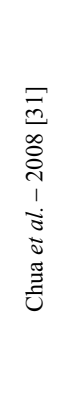 & $\begin{array}{l}\text { typ. }+ \\
\text { atyp }\end{array}$ & - & $\begin{array}{c}15 \mathrm{FE} \\
\\
-\end{array}$ & 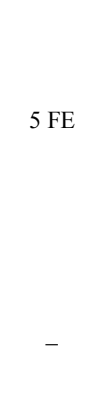 & $\begin{array}{c}25 \mathrm{AN} \\
\\
- \\
-\end{array}$ & $\begin{array}{l}\text { typ.+atyp. vs AN } \\
\text { after 3-4 weeks: } \\
\text { GMV excess in 1) L } \\
\text { CG extending to L } \\
\text { medial FC,L caudate } \\
\text { nucleus ( } 9 \% \text { ) (BA 0, } \\
\text { BA 24) } \\
\text { 2) R CG extending } \\
\text { to R caudate nucleus } \\
\text { (10\%) (BA 0, BA } \\
\text { 24) }\end{array}$ & 93 & $\begin{array}{c}-0.6 \\
21.8 \\
5.1 \\
\\
\\
\\
\\
4.9 \\
21.2 \\
2.4\end{array}$ & - & 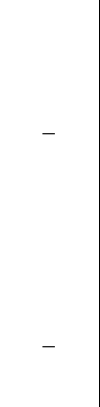 & . & - \\
\hline & 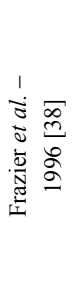 & atyp. & 8 & - & 8 & - & - & - & - & $\begin{array}{c}\text { baseline: caudate } \bar{A} \text { in } \\
\text { COS vs C, 2years } ̈ \text { A } \\
\text { no diff. between } 2 \\
\text { groups, non-sign. } \\
\text { putamen volume in } \\
\text { COS vs C, non-sign. } \\
\text { Āof lateral } \\
\text { ventricles in } \\
\text { COS vs C }\end{array}$ & - & - & - \\
\hline & 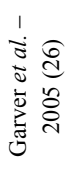 & $\begin{array}{l}\text { typ. }+ \\
\text { atyp }\end{array}$ & 7 & $6(3 \mathrm{FE})$ & $\begin{array}{c}13 \\
(7 \mathrm{FE})\end{array}$ & - & no effect & - & - & $\begin{array}{c}\text { Āof cortical gray } \\
\text { volume, of CSF } \\
\text { and WM volumes, no } \\
\text { effects on the basal } \\
\text { ganglia }\end{array}$ & - & - & $\begin{array}{l}\text { cerebral cortical gray } \\
\text { expanded, no effects } \\
\text { on the basal ganglia }\end{array}$ \\
\hline & 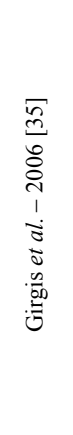 & atyp. & 15 & - & $15 \mathrm{AN}$ & - & - & - & - & $\begin{array}{c}\text { between baseline and } \\
\text { follow-up A AM: 1) } \\
\text { L superior TG } \\
\text { (BA39) 2) L middle } \\
\text { TG (BA39) and } \\
\text { GM 3) LFG, rectal } \\
\text { gyrus (BA11) WM } \\
\text { 4) L cerebrum, } \\
\text { subjacent to FG 5) L } \\
\text { corpus callosum 6) R } \\
\text { cerebrum, subjacent } \\
\text { to FG, 7) R corpus } \\
\text { callosum 8) R AC }\end{array}$ & & $\begin{array}{l}\text { 1) }-45,-59,19 \\
\text { 2) }-57,-54,14 \\
\text { 3) }-2,43,-26 \\
\text { 4) }-19,22,17 \\
\text { and } \\
-16,16,21 \\
\text { 5)-10,23,15 } \\
\text { 6) } 23,19,18 \\
\text { 7) } 15,17,21 \\
\text { 8) } 7,28,15\end{array}$ & - \\
\hline & 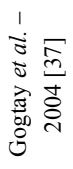 & atyp. & 38 & - & 23 & - & - & - & - & - & - & - & $\begin{array}{l}\text { longitudinally less } \\
\mathrm{P}, \mathrm{F}, \mathrm{T} \text {, total GMV }\end{array}$ \\
\hline & 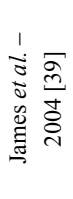 & atyp. & 16 & - & $16 \mathrm{COS}$ & - & - & - & - & $\begin{array}{r}\text { patients (all medicate } \\
\text { the prefrontal cortex } \\
(\mathrm{p}=0.04) \mathrm{vs} \mathrm{C} \text {; large } \\
\text { ventricle }(\mathrm{p}=0.05) ; \text { lon } \\
\text { of progression in } \mathrm{p} \\
\text { volume a }\end{array}$ & $\begin{array}{l}\text { d) had } \mathrm{m} \\
(\mathrm{p}<0.001) \\
\mathrm{r} \text { volumes } \\
\text { gitudinally } \\
\text { sterior inf } \\
\text { monge mal }\end{array}$ & $\begin{array}{l}\text { ean volume in } \\
\text { and thalamus } \\
\text { of the fourth } \\
\text { only evidence } \\
\text { erior vermis } \\
\text { les }\end{array}$ & - \\
\hline
\end{tabular}


(Table 3) contd....

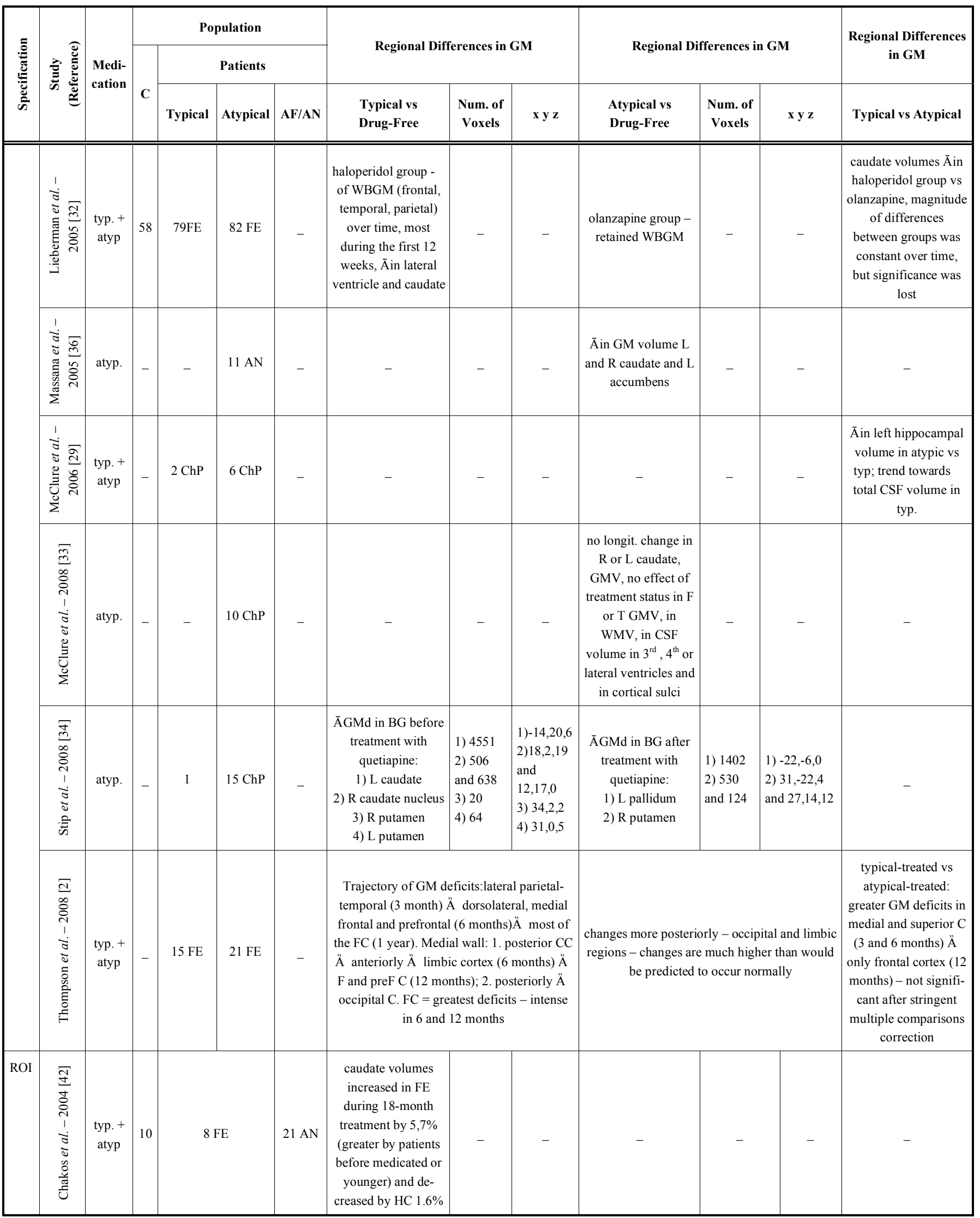


(Table 3) contd....

\begin{tabular}{|c|c|c|c|c|c|c|c|c|c|c|c|c|c|}
\hline \multirow{2}{*}{ 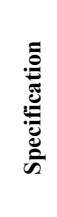 } & \multirow{2}{*}{ 胥 } & \multirow{2}{*}{$\begin{array}{l}\text { Medi- } \\
\text { cation }\end{array}$} & \multicolumn{4}{|c|}{ Population } & \multirow{2}{*}{\multicolumn{3}{|c|}{ Regional Differences in GM }} & \multirow{2}{*}{\multicolumn{3}{|c|}{ Regional Differences in GM }} & \multirow{2}{*}{$\begin{array}{l}\text { Regional Differences } \\
\text { in GM }\end{array}$} \\
\hline & & & C & \multicolumn{3}{|c|}{ Patients } & & & & & & & \\
\hline & 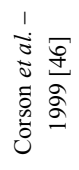 & $\begin{array}{l}\text { typ. }+ \\
\text { atyp }\end{array}$ & - & $\begin{array}{l}13 \mathrm{FE} \\
(5 \text { typ }+ \\
\text { atyp. })\end{array}$ & $\begin{array}{c}10 \mathrm{FE} \\
(4 \text { atyp }+ \\
\text { typ. })\end{array}$ & - & $\begin{array}{c}\text { typ.: Āvolume of } \\
\text { caudate and lentiform } \\
\text { nucleus }\end{array}$ & - & - & $\begin{array}{c}\text { atyp.: volume of } \\
\text { caudate and lentiform } \\
\text { nucleus }\end{array}$ & - & - & - \\
\hline & 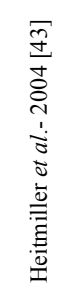 & atyp. & 14 & - & $\begin{array}{l}14 \mathrm{AN} \\
\mathrm{FE}\end{array}$ & - & - & - & - & $\begin{array}{l}\text { negligible Āin volume } \\
\text { of the caudate over } 2 \\
\text { years; females - the } \\
\text { greater amount of drug } \\
\text { exposure, the less } \\
\text { enlargement , males - } \\
\text { opposite - the greater } \\
\text { the enlargement of } \\
\text { caudate }\end{array}$ & - & - & - \\
\hline & 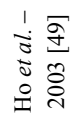 & $\begin{array}{l}\text { typ. }+ \\
\text { atyp }\end{array}$ & 23 & $73(33 \mathrm{~A}$ & $\mathrm{N}, 40 \mathrm{RO})$ & - & $\begin{array}{r}\text { no significant effects } \mathrm{fi} \\
\text { ROIs - progres }\end{array}$ & $\begin{array}{l}\text { rom } 4 \text { treat } \\
\text { sive volum }\end{array}$ & $\begin{array}{l}\text { ent (typ } \\
\text { ric brai }\end{array}$ & $\begin{array}{l}\text { atyp.; typ.+ atyp.; clozapi } \\
\text { changes despite antipsych }\end{array}$ & $\begin{array}{l}\text { e) measures } \\
\text { ic treatment }\end{array}$ & $\mathrm{n}$ any & - \\
\hline & 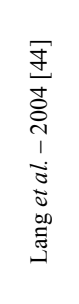 & $\begin{array}{l}\text { typ. }+ \\
\text { atyp }\end{array}$ & 23 & $10 \mathrm{ChP}$ & $\begin{array}{l}37(13 \\
\text { switched } \\
\text { from } \\
\text { risperi- } \\
\text { odne, } 14 \\
\text { contin- } \\
\text { ued) }\end{array}$ & - & $\begin{array}{l}\text { baseline: typ. - BG } \\
\text { greater (putamen by } \\
7 \% \text {, globus pallidus } \\
20.7 \% \text { ) vs contols Ä } \\
\text { switch to olanzapine: } \\
\text { putamen volume by } \\
9.8 \%+\text { globus pallidus } \\
\text { by } 10.7 \% \text { - did not } \\
\text { differ from controls }\end{array}$ & - & - & $\begin{array}{c}\text { risperidone-treated } \\
\text { switched Ä olanzapine: } \\
\text { no significant differ- } \\
\text { ences in overall BG }\end{array}$ & - & - & $\begin{array}{l}\text { switch to olanzapine: } \\
\text { putamen volume by } \\
9.8 \%+\text { globus pal- } \\
\text { lidus by } 10.7 \% \text { Ä did } \\
\text { not differ from } \\
\text { controls }\end{array}$ \\
\hline & 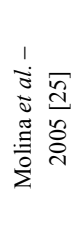 & atyp. & 11 & - & $\begin{array}{c}12 \mathrm{ChP} \\
\mathrm{TR}\end{array}$ & $17 \mathrm{AN}$ & $\begin{array}{l}\text { baseline: ChP TR typ., } \\
\text { than atyp. }\end{array}$ & - & - & $\begin{array}{l}\text { AN baseline: Āin O GM } \\
\text { tudinally: the greater the } \\
\text { increase in GM + the gre } \\
\text { in total and O WM, the } \\
\text { in total, F GM, P and O } \\
\text { tudinally: the gre } \\
\text { the great }\end{array}$ & $\begin{array}{l}\text { P GM vs C } \\
\text { iitial deficit } \\
\text { ter the initia } \\
\text { eater the lo } \\
\text { M vs C }+ \\
\text { er the baseli } \\
\text { the in tota }\end{array}$ & $\begin{array}{l}\text { in to } \\
\text { total a } \\
\text { excess } \\
\text { gitudina } \\
\text { total, } \\
\text { e volun } \\
\text { F, P ar }\end{array}$ & $\begin{array}{l}\text { 1+O WM vs C; longi- } \\
\text { d P GM, the greater the } \\
\text { tal WM and its change } \\
\text { decreases; ChP TR: } \bar{A} \\
\text { P, O WM vs C; longi- } \\
\text { excess of WM, } \\
\text { O WM }\end{array}$ \\
\hline & 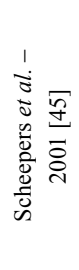 & atyp. & - & - & $\begin{array}{l}26 \text { (typ. } \\
\text { before) }\end{array}$ & - & - & - & - & - & - & - & $\begin{array}{l}\text { clozapine in CNV } \\
\text { after typ. treatment; } \\
\text { no difference in } \mathrm{CNV} \\
\text { changes between } \\
\text { responders and non- } \\
\text { responders, no } \\
\text { changes in total brain } \\
\text { volume }\end{array}$ \\
\hline & 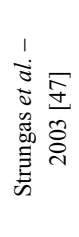 & atyp. & 5 & - & $\begin{array}{l}7 \text { (3 FE, } \\
4 \mathrm{ChP})\end{array}$ & - & - & - & - & $\begin{array}{c}\text { drug-free period: } \\
\text { patients - trend smaller } \\
\text { thalamic volumes } \\
(\mathrm{p}<0.06) ; 4 \text { weeks of } \\
\text { treatment: volumetric } \\
\text { expansion of } \mathrm{L} \text { and } \mathrm{R} \\
\text { thalamus }\end{array}$ & - & - & - \\
\hline
\end{tabular}


(Table 3) contd....

\begin{tabular}{|c|c|c|c|c|c|c|c|c|c|c|c|c|c|}
\hline \multirow{2}{*}{ 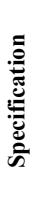 } & \multirow{2}{*}{ 胥 } & \multirow{2}{*}{$\begin{array}{l}\text { Medi- } \\
\text { cation }\end{array}$} & \multicolumn{4}{|c|}{ Population } & \multirow{2}{*}{\multicolumn{3}{|c|}{ Regional Differences in GM }} & \multirow{2}{*}{\multicolumn{3}{|c|}{ Regional Differences in GM }} & \multirow{2}{*}{$\begin{array}{l}\text { Regional Differences } \\
\text { in GM } \\
\text { Typical vs Atypical }\end{array}$} \\
\hline & & & C & \multicolumn{3}{|c|}{ Patients } & & & & & & & \\
\hline & 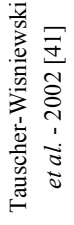 & $\begin{array}{l}\text { typ. }+ \\
\text { atyp }\end{array}$ & - & 4 & 9 & 8 & - & - & - & $\begin{array}{c}\text { age-related Äin } \\
\text { CNV 9\% between } \\
\text { baseline and follow- } \\
\text { up in FE as well as } \\
\text { C }\end{array}$ & - & - & - \\
\hline & 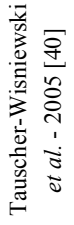 & atyp. & 37 & - & $10 \mathrm{AN}$ & - & - & - & - & $\begin{array}{c}\text { no difference } \\
\text { between baseline } \\
\text { and endpoint in } \\
\mathrm{CNV}\end{array}$ & - & - & - \\
\hline
\end{tabular}

All studies are also referenced in the text. Abbreviations $\mathrm{x}, \mathrm{y}, \mathrm{z}=$ Talairach coordinates (MNI coordinates uncounted by www.bioimagesuite.org/Mni2Tal/index.html); $\mathrm{C}=\mathrm{control}$; $\mathrm{AN}$ $=$ antipsychotic naïve; $\mathrm{AF}=$ antipsychotic free; $\mathrm{PT}=$ previously treated; $\mathrm{FE}=$ first episode; $\mathrm{RO}=$ recent onset; $\mathrm{TR}=$ chronic resistant $\mathrm{ChP}=$ chronic patient; $\mathrm{BG}=$ basal ganglia; $\overline{\mathrm{A}}=$ excess, increase, higher; $\ddot{A}=$ decrease, deficit; $\mathrm{R}=$ right; $\mathrm{L}=$ left; $\mathrm{TG}=$ temporal gyrus; $\mathrm{FG}=$ frontal gyrus; $\mathrm{CG}=$ cingulate gyrus; $\mathrm{BA}=\mathrm{Brodmann}$ area; typ. = typical antipsychotics; atyp. = atypical antipsychotics; $\mathrm{GMV}=$ gray matter volume, $\mathrm{GMd}=$ gray matter density; $\mathrm{WM} \mathrm{V}=$ white matter volume; $\mathrm{WBGM}=$ whole brain gray matter; $\mathrm{FC}=$ frontal cortex; $\mathrm{CC}=$ cingulate cortex; $\mathrm{ACC}=$ anterior cingulate cortex; CSF $=$ cerebrospinal fluid; $\mathrm{COS}=$ childhood onset schizophrenia; typ. $=$ typicals; atyp. $=$ atypicals; SAPS $=\mathrm{Schedule}$ for assessment of positive symptoms; FGM = frontal gray matter; OGM = occipital GM; PGM = parietal GM; DLFG = dorsolateral frontal gyrus; SMA = supplementary motor area; CNV = caudate nuclei volume

seen among the four different treatment groups (typical antipsychotics, atypical antipsychotics, typical + atypical antipsychotics, clozapine) [49]. The specifics of each of these longitudinal ROI studies have been included in Table 3.

\section{DISCUSSION}

Structural neuroimaging studies can be used to examine the influence of antipsychotics on brain structure. Overall, structural imaging studies suggest that medication with typical antipsychotics leads to an increased volume of the basal ganglia, while atypical antipsychotics reduce this volume after switching.

\section{Effects of Antipsychotic Medication on Structural Neuro- imaging Measures in Schizophrenia}

There is a convergence of findings from structural neuroimaging studies described showing volumetric reductions in fronto-temporo-limbic regions may reflect pathophysiologic processes of schizophrenia $[9,12]$. Studies of patients with schizophrenia demonstrate robust volumetric reductions in multiple brain regions and particularly in the prefrontal cortex and of the superior and medial temporal lobes and in the anterior cingulate [4, 11-14].

While these findings are consistent and replicated, there are inconsistencies regarding the potential effect of antipsychotic medication. Some studies found no significant effect of antipsychotic medication on brain structure [30, 33, 40, $41,49]$. However, in many of these studies, the sample sizes were modest ( $<30$ subjects) resulting in type 2 errors. Other studies found ameliorative effects of (mostly atypical) antipsychotics on structural neuroimaging measures $[38,44,50$,
51]. Generally, both typical and atypical antipsychotics respectively the illness process itself were associated with GM volume reductions in occipital and limbic regions [2].

In general, functional imaging studies underline findings from structural neuroimaging studies. They suggest that treatment with atypical antipsychotics has been associated with greater regional cortical activity compared to treatment with typical antipsychotic drugs, whereas the latter have been associated with relatively more striatal activity [52]. Atypical antipsychotics (substitution of risperidone for typical antipsychotic) also increased prefrontal activity (prefrontal cortex, supplementary motor area) during cognitive tasks (working memory) and reduced abnormally elevated subcortical limbic activity during emotion processing so that brain activity resembled that observed in healthy volunteers [50]. These findings might reflect pathophysiologic processes that may be at least partly ameliorated by antipsychotic medication. Clozapine but not haloperidol treatment re-established normal task-activated regional cerebral blood flow (CBF) patterns in schizophrenia in the ACC [53]. This is consistent with the finding that atypical antipsychotics might have a greater effect on cognitive impairment in schizophrenia than typical [54].

Progressive brain changes in schizophrenia are considered controversial [55]. Although there is evidence for GM loss and ventricular enlargement from prospective studies of patients with first episode and chronic schizophrenia [49, 5661 , the potential confounding impact of antipsychotics is still debatable. Most neuroimaging studies of schizophrenia to date have not included the examination of non-medicated patients, making conclusions about medication effects on 
neuroimaging measures difficult. Investigation of subjects at the onset of the disease avoids potential confounders such as antipsychotic treatment [62-65]. A clinical high-risk status for psychosis (at risk mental state, ARMS) is associated with a set of neurofunctional abnormalities that are qualitatively similar to those observed in patients with the disorder [66]. As these findings are not attributable to chronic psychotic symptoms [67] and antipsychotic treatment, they may represent markers of increased vulnerability to psychotic disorders. Structural MRI studies of non-medicated patients in a prodromal phase of psychosis or ARMS demonstrated that neuroanatomical abnormalities are already evident in the very early phase of psychosis. People at high risk of psychosis show qualitatively similar volumetric abnormalities to patients with schizophrenia. Cortical brain abnormalities have been found in genetically defined high-risk populations such as first-degree relatives and co-twins of patients with schizophrenia, as well in people with ARMS [13, 68-80]. Previous longitudinal MRI studies in this group found that the subset of patients who developed psychosis showed a longitudinal reduction in GM in the orbito-frontal, temporal lobe, parietal lobe and cerebellum [79, 81, 82].

\section{Mechanisms of Antipsychotic Action on Brain Structure}

At present, the mechanism of action of antipsychotics is inferred from animal and in vitro studies. Structural neuroimaging has contributed substantially to the understanding of the mechanisms of action of existing antipsychotic drugs. Thompson et al. [2] suggest pharmacologic mechanisms that go beyond symptom suppression via neuroreceptor antagonism. Those mechanisms might ameliorate the underlying pathophysiology that causes disease progression and the clinical deterioration that is the hallmark of the illness [2].

Furthermore, it has been suggested that antipsychotics might increase neurogenesis, however, neurogenesis seems contradictory to studies showing that antipsychotics are associated with volume reductions. Haloperidol treatment may be neurotoxic $[25,83]$ which may explain the cortical GM volume reduction. In a very recent study, Konopaske et al. [84] found a significant $20.5 \%$ reduction in astrocyte numbers and a non-significant $12.9 \%$ reduction in oligodendrocytes in antipsychotic-exposed macaque monkeys. Similar effects were seen in both haloperidol and olanzapine treated patients. These very intriguing findings of antipsychoticinduced glial cell number reduction in animals, however, need to be replicated. In humans, treated with typical antipsychotics, frontal GM volume reduction is correlated with the dose [3]. Medication-free subjects with an ARMS show fronto-temporal tissue reduction relative to healthy controls $[79,81,82]$, suggesting that the loss process is not attributable solely to medication.

Atypical antipsychotics reduce oxidative stress [85] and stimulate the synthesis of trophic molecules [85-88]. In primates, treatment with atypical antipsychotics led to prefrontal glial cell proliferation and cortical hypertrophy [89]. In rats, olanzapine stimulates glial cell division in the frontal cortex [85]. Thus, atypical antipsychotics may reduce disturbed myelination and abnormally severe dendritic pruning and/or neurotoxic ablation of synapses $[49,90,91]$ in patients with schizophrenia. Atypical antipsychotics may also induce oligodendrocyte proliferation and compensate for oligodendrocyte reductions [49] and intracortical myelination [90].

\section{Methodological Issues in Studies Investigating Medica- tion Effects by Neuroimaging}

Some studies used VBM, a technique that allows comparisons of the entire brain volume at the single voxel level. Mostly, an 'optimized' VBM method [92] is used to minimize the potentially confounding effects of errors in stereotactic normalization was used. It is important to note that to identify regional differences in GM volume instead of GM concentration, 'modulated' versions of VBM, which involves the multiplication of the spatially normalized GM by its relative volume before and after warping, were used. However, the use of VBM implicates problems of brain registration [93]. The size of the smoothing kernel is also relevant, because it should be roughly the size of the expected findings. Although the exact meaning of the volumetric abnormalities is not entirely clear, GM reductions may reflect a variety of neuropathological changes, e.g. exaggerated dendritic or synaptic pruning [94], impaired myelination [90], apoptosis [95], or other neurotoxic effects of first-generation antipsychotic medications [96]. Furthermore, differences in scanning parameters and image analysis may account for inconsistencies in neuroimaging measures.

The results of this review raise ethical questions on antipsychotic use. If antipsychotic medication may lead - at least in some patients - to GM volume reduction careful benefitrisk decisions have to be made for individual patients. Patients with schizophrenia should be very cautiously informed about the potential risks (and of course benefits) of antipsychotic medication.

For future studies, we suggest to focus on, longitudinal designs that represent the gold standard for investigation of medication effects. These studies have clearly the advantage of powerful, within-subject designs. Small sample sizes, heterogeneity in the sociodemographic characteristics of the subjects, lack of consistency between scanning parameters also suggest future multi-site studies that have shown the potential to overcome most of these problems and to bridge basic neuroscience with clinical psychiatry.

\section{CONCLUSIONS}

In patients with schizophrenia treated with antipsychotics, reduced GM volume is described, particularly in frontal and temporal lobes. Medication with typical antipsychotics also leads to increased volume of the basal ganglia, while atypical antipsychotics reversed the effect after switching.

Neuroimaging studies have provided compelling evidence that despite antipsychotic medication (both typical and atypical) there are detectable anatomical changes at the level of total and regional brain volumes. To date, it remains elusive whether the effects of antipsychotic medication on GM volume are simply beneficial. It is questionable whether the effects we are observing are the direct effects of antipsychotics or whether these measures are actually surrogates for third variables. It is also possible that the opposite could be true, that antipsychotics may attenuate the brain changes and 
that compliance with medication could lead to less progressive change than non-compliance. Unless we do not have more reliable studies from non-medicated patients, the potential impact of the confounding effect of medication has to be kept in mind. So far, the investigation of patients at risk or with a first-episode of schizophrenia seems to be the most promising alternative.

\section{CONFLICT OF INTEREST}

This research was supported by the Swiss National Science Foundation (No. 3232BO 119382/1) and the Novartis Foundation. The sponsor of the study had no role in study design, collection, analysis, interpretation of data, writing of this report, and in the decision to submit the paper for publication.

\section{ABBREVIATIONS}

$$
\begin{array}{ll}
\mathrm{ACC} & =\text { Anterior cingulate cortex } \\
\mathrm{ARMS} & =\text { At risk mental state } \\
\mathrm{CBF} & =\text { Cerebral blood flow } \\
\mathrm{CSF} & =\text { Cerebrospinal fluid } \\
\mathrm{DSM} & =\text { Diagnostic and statistic manual of mental } \\
\mathrm{GM} & \text { disorders } \\
\mathrm{MRI} & =\text { Mray matter } \\
\mathrm{ROI} & =\text { Region-of-interest } \\
\mathrm{VBM} & =\text { Voxel-based morphometry } \\
\mathrm{WM} & =\text { White matter }
\end{array}
$$

\section{REFERENCES}

References 97-99 are related articles recently published.

[1] Lopez AD, Murray CC. The global burden of disease, 1990-2020. Nat Med 1998 ; 4(11): 1241-3.

[2] Thompson PM, Bartzokis G, Hayashi KM, Klunder AD, Lu PH, Edwards $\mathrm{N}$, et al. Time-Lapse Mapping of Cortical Changes in Schizophrenia with Different Treatments. Cereb Cortex. 2008; [Epub ahead of print].

[3] Gur RE, Maany V, Mozley PD, Swanson C, Bilker W, Gur RC. Subcortical MRI volumes in neuroleptic-naive and treated patients with schizophrenia. Am J Psychiatry 1998; 155(12): 1711-7.

[4] Honea R, Crow TJ, Passingham D, Mackay CE. Regional deficits in brain volume in schizophrenia: a meta-analysis of voxel-based morphometry studies. Am J Psychiatry 2005; 162(12): 2233-45.

[5] Seeman P, Chau-Wong M, Tedesco J, Wong K. Brain receptors for antipsychotic drugs and dopamine: direct binding assays. Proc Natl Acad Sci USA 1975; 72(11): 4376-80.

[6] Carlsson A. Antipsychotic drugs, neurotransmitters, and schizophrenia. Am J Psychiatry 1978; 135(2): 165-73.

[7] Lieberman JA, Bymaster FP, Meltzer HY, Deutch AY, Duncan GE, Marx CE, et al. Antipsychotic drugs: comparison in animal models of efficacy, neurotransmitter regulation, and neuroprotection. Pharmacol Rev 2008; 60(3): 358-403.

[8] Meltzer HY, Li Z, Kaneda Y, Ichikawa J. Serotonin receptors: their key role in drugs to treat schizophrenia. Prog Neuropsychopharmacol Biol Psychiatry 2003; 27(7): 1159-72.

[9] Shenton ME, Dickey CC, Frumin M, McCarley RW. A review of MRI findings in schizophrenia. Schizophr Res 2001; 49(1-2): 1-52.

[10] Wright P, Nimgaonkar VL, Donaldson PT, Murray RM. Schizophrenia and HLA: a review. Schizophr Res 2001; 47(1): 1-12.
[11] Lawrie SM, Abukmeil SS. Brain abnormality in schizophrenia. A systematic and quantitative review of volumetric magnetic resonance imaging studies. Br J Psychiatry 1998; 172: 110-20.

[12] Wright IC, Rabe-Hesketh S, Woodruff PW, David AS, Murray RM, Bullmore ET. Meta-analysis of regional brain volumes in schizophrenia. Am J Psychiatry 2000; 157(1): 16-25.

[13] Lawrie SM, Whalley H, Kestelman JN, Abukmeil SS, Byrne M, Hodges A, et al. Magnetic resonance imaging of brain in people at high risk of developing schizophrenia. Lancet 1999; 353(9146): 303.

[14] Gur RE, Keshavan MS, Lawrie SM. Deconstructing psychosis with human brain imaging. Schizophr Bull 2007; 33(4): 921-31.

[15] Harrison PJ, Freemantle N, Geddes JR. Meta-analysis of brain weight in schizophrenia. Schizophr Res 2003; 64(1): 25-34.

[16] Harrison PJ. The neuropathological effects of antipsychotic drugs. Schizophr Res 1999; 40(2): 87-99.

[17] Konradi C, Heckers S. Antipsychotic drugs and neuroplasticity: insights into the treatment and neurobiology of schizophrenia. Biol Psychiatry 2001; 50(10): 729-42.

[18] Scherk H, Falkai P. Effects of antipsychotics on brain structure. Curr Opin Psychiatry 2006; 19(2): 145-50.

[19] Phillips ML, Travis MJ, Fagiolini A, Kupfer DJ. Medication effects in neuroimaging studies of bipolar disorder. Am J Psychiatry 2008; 165(3): 313-20.

[20] Sikich L. Efficacy of atypical antipsychotics in early-onset schizophrenia and other psychotic disorders. J Clin Psychiatry 2008; 69 Suppl 4: 21-5.

[21] Vita A, De Peri L. The effects of antipsychotic treatment on cerebral structure and function in schizophrenia. Int Rev Psychiatry 2007; 19(4): 429-36.

[22] Pressler M, Nopoulos P, Ho BC, Andreasen NC. Insular cortex abnormalities in schizophrenia: Relationship to symptoms and typical neuroleptic exposure. Biol Psychiatry 2005; 57(4): 394-8.

[23] Chakos MH, Schobel SA, Gu H, Gerig G, Bradford D, Charles C, et al. Duration of illness and treatment effects on hippocampal volume in male patients with schizophrenia. Br J Psychiatry 2005; 186: 26-31.

[24] Kopelman A, Andreasen NC, Nopoulos P. Morphology of the anterior cingulate gyrus in patients with schizophrenia: relationship to typical neuroleptic exposure. Am J Psychiatry 2005; 162(10): 1872-8.

[25] Molina V, Reig S, Sanz J, Palomo T, Benito C, Sanchez J, et al. Increase in gray matter and decrease in white matter volumes in the cortex during treatment with atypical neuroleptics in schizophrenia. Schizophr Res 2005; 80(1): 61-71.

[26] Garver DL, Holcomb JA, Christensen JD. Cerebral cortical gray expansion associated with two second-generation antipsychotics. Biol Psychiatry 2005; 58(1): 62-6.

[27] Dazzan P, Morgan KD, Orr K, Hutchinson G, Chitnis X, Suckling $\mathrm{J}$, et al. Different effects of typical and atypical antipsychotics on grey matter in first episode psychosis: the AESOP study. Neuropsychopharmacology 2005; 30(4): 765-74.

[28] Pariante CM, Dazzan P, Danese A, Morgan KD, Brudaglio F, Morgan $\mathrm{C}$, et al. Increased pituitary volume in antipsychotic-free and antipsychotic-treated patients of the AEsop first-onset psychosis study. Neuropsychopharmacology 2005; 30(10): 1923-31.

[29] McClure RK, Phillips I, Jazayerli R, Barnett A, Coppola R, Weinberger DR. Regional change in brain morphometry in schizophrenia associated with antipsychotic treatment. Psychiatry Res 2006; 148(2-3): 121-32.

[30] Christensen J, Holcomb J, Garver DL. State-related changes in cerebral white matter may underlie psychosis exacerbation. Psychiatry Res 2004; 130(1): 71-8.

[31] Chua SE, Deng Y, Chen EY, Law CW, Chiu CP, Cheung C, et al. Early striatal hypertrophy in first-episode psychosis within 3 weeks of initiating antipsychotic drug treatment. Psychol Med 2008: 1-8.

[32] Lieberman JA, Tollefson GD, Charles C, Zipursky R, Sharma T, Kahn RS, et al. Antipsychotic drug effects on brain morphology in first-episode psychosis. Arch Gen Psychiatry 2005; 62(4): 361-70.

[33] McClure RK, Carew K, Greeter S, Maushauer E, Steen G, Weinberger DR. Absence of regional brain volume change in schizophrenia associated with short-term atypical antipsychotic treatment. Schizophr Res 2008; 98(1-3): 29-39.

[34] Stip E, Mancini-Marie A, Fahim C, Bentaleb LA, Letourneau G, Potvin S. Decrease in basal ganglia grey matter density associated 
with atypical antipsychotic treatment in schizophrenia patients. Schizophr Res 2008; 103(1-3): 319-21.

[35] Girgis RR, Diwadkar VA, Nutche JJ, Sweeney JA, Keshavan MS, Hardan AY. Risperidone in first-episode psychosis: a longitudinal, exploratory voxel-based morphometric study. Schizophr Res 2006; 82(1): 89-94.

[36] Massana G, Salgado-Pineda P, Junque C, Perez M, Baeza I, Pons $\mathrm{A}$, et al. Volume changes in gray matter in first-episode neuroleptic-naive schizophrenic patients treated with risperidone. J Clin Psychopharmacol 2005; 25(2): 111-7.

[37] Gogtay N, Sporn A, Clasen LS, Nugent TF, 3rd, Greenstein D, Nicolson R, et al. Comparison of progressive cortical gray matter loss in childhood-onset schizophrenia with that in childhood-onset atypical psychoses. Arch Gen Psychiatry 2004; 61(1): 17-22.

[38] Frazier JA, Giedd JN, Kaysen D, Albus K, Hamburger S, Alaghband-Rad J, et al. Childhood-onset schizophrenia: brain MRI rescan after 2 years of clozapine maintenance treatment. Am J Psychiatry 1996; 153(4): 564-6.

[39] James AC, James S, Smith DM, Javaloyes A. Cerebellar, prefrontal cortex, and thalamic volumes over two time points in adolescentonset schizophrenia. Am J Psychiatry 2004; 161(6): 1023-9.

[40] Tauscher-Wisniewski S, Tauscher J, Christensen BK, Mikulis DJ, Zipursky RB. Volumetric MRI measurement of caudate nuclei in antipsychotic-naive patients suffering from a first episode of psychosis. J Psychiatr Res 2005; 39(4): 365-70.

[41] Tauscher-Wisniewski S, Tauscher J, Logan J, Christensen BK, Mikulis DJ, Zipursky RB. Caudate volume changes in first episode psychosis parallel the effects of normal aging: a 5-year follow-up study. Schizophr Res 2002; 58(2-3): 185-8.

[42] Chakos MH, Lieberman JA, Bilder RM, Borenstein M, Lerner G, Bogerts B, et al. Increase in caudate nuclei volumes of first-episode schizophrenic patients taking antipsychotic drugs. Am J Psychiatry 1994; 151(10): 1430-6.

[43] Heitmiller DR, Nopoulos PC, Andreasen NC. Changes in caudate volume after exposure to atypical neuroleptics in patients with schizophrenia may be sex-dependent. Schizophr Res 2004; 66(2-3): $137-42$.

[44] Lang DJ, Kopala LC, Vandorpe RA, Rui Q, Smith GN, Goghari $\mathrm{VM}$, et al. Reduced basal ganglia volumes after switching to olanzapine in chronically treated patients with schizophrenia. Am J Psychiatry 2004; 161(10): 1829-36.

[45] Scheepers FE, de Wied CC, Hulshoff Pol HE, van de Flier W, van der Linden JA, Kahn RS. The effect of clozapine on caudate nucleus volume in schizophrenic patients previously treated with typical antipsychotics. Neuropsychopharmacology 2001; 24(1): 4754 .

[46] Corson PW, Nopoulos P, Miller DD, Arndt S, Andreasen NC. Change in basal ganglia volume over 2 years in patients with schizophrenia: typical versus atypical neuroleptics. Am J Psychiatry $1999 ; 156(8): 1200-4$.

[47] Strungas S, Christensen JD, Holcomb JM, Garver DL. State-related thalamic changes during antipsychotic treatment in schizophrenia: preliminary observations. Psychiatry Res 2003; 124(2): 121-4.

[48] McCormick L, Decker L, Nopoulos P, Ho BC, Andreasen N. Effects of atypical and typical neuroleptics on anterior cingulate volume in schizophrenia. Schizophr Res 2005; 80(1): 73-84.

[49] Ho BC, Andreasen NC, Nopoulos P, Arndt S, Magnotta V, Flaum M. Progressive structural brain abnormalities and their relationship to clinical outcome: a longitudinal magnetic resonance imaging study early in schizophrenia. Arch Gen Psychiatry 2003; 60(6): 585-94.

[50] Honey GD, Bullmore ET, Soni W, Varatheesan M, Williams SC, Sharma T. Differences in frontal cortical activation by a working memory task after substitution of risperidone for typical antipsychotic drugs in patients with schizophrenia. Proc Natl Acad Sci USA 1999; 96(23): 13432-7.

[51] Braus DF, Ende G, Weber-Fahr W, Demirakca T, Tost H, Henn FA. Functioning and neuronal viability of the anterior cingulate neurons following antipsychotic treatment: MR-spectroscopic imaging in chronic schizophrenia. Eur Neuropsychopharmacol 2002; 12(2): $145-52$

[52] Honey GD, Fletcher PC, Bullmore ET. Functional brain mapping of psychopathology. J Neurol Neurosurg Psychiatry 2002; 72(4): 432-9.

[53] Lahti AC, Holcomb HH, Weiler MA, Medoff DR, Frey KN, Hardin $\mathrm{M}$, et al. Clozapine but not haloperidol Re-establishes normal task-activated rCBF patterns in schizophrenia within the anterior cingulate cortex. Neuropsychopharmacology 2004; 29(1): 171-8.

[54] Meltzer HY, McGurk SR. The effects of clozapine, risperidone, and olanzapine on cognitive function in schizophrenia. Schizophr Bull 1999; 25(2): 233-55.

[55] DeLisi LE. Reviewing the "facts about schizophrenia: : a possible or impossible task? Schizophr Res 2008; 102(1-3): 19-20.

[56] Cahn W, Hulshoff Pol HE, Lems EB, van Haren NE, Schnack HG, van der Linden JA, et al. Brain volume changes in first-episode schizophrenia: a 1-year follow-up study. Arch Gen Psychiatry 2002; 59(11): 1002-10.

[57] Kasai K, Shenton ME, Salisbury DF, Onitsuka T, Toner SK, Yurgelun-Todd D, et al. Differences and similarities in insular and temporal pole MRI gray matter volume abnormalities in firstepisode schizophrenia and affective psychosis. Arch Gen Psychiatry 2003; 60(11): 1069-77.

[58] Kubicki M, Shenton ME, Salisbury DF, Hirayasu Y, Kasai K, Kikinis R, et al. Voxel-based morphometric analysis of gray matter in first episode schizophrenia. Neuroimage 2002; 17(4): 1711-9.

[59] Mathalon DH, Sullivan EV, Lim KO, Pfefferbaum A. Progressive brain volume changes and the clinical course of schizophrenia in men: a longitudinal magnetic resonance imaging study. Arch Gen Psychiatry 2001; 58(2): 148-57.

[60] Sporn AL, Greenstein DK, Gogtay N, Jeffries NO, Lenane M, Gochman $\mathrm{P}$, et al. Progressive brain volume loss during adolescence in childhood-onset schizophrenia. Am J Psychiatry 2003; 160(12): 2181-9.

[61] Wood SJ, Velakoulis D, Smith DJ, Bond D, Stuart GW, McGorry $\mathrm{PD}$, et al. A longitudinal study of hippocampal volume in first episode psychosis and chronic schizophrenia. Schizophr Res 2001; 52(1-2): 37-46

[62] Gschwandtner U, Aston J, Borgwardt S, Drewe M, Feinendegen C, Lacher D, et al. Neuropsychological and neurophysiological findings in individuals suspected to be at risk for schizophrenia: preliminary results from the Basel early detection of psychosis study Fruherkennung von Psychosen (FEPSY). Acta Psychiatr Scand 2003; 108(2): 152-5

[63] Gschwandtner U, Pfluger M, Aston J, Borgwardt S, Drewe M, Stieglitz RD, et al. Fine motor function and neuropsychological deficits in individuals at risk for schizophrenia. Eur Arch Psychiatry Clin Neurosci 2006; 256(4): 201-6.

[64] Riecher-Rossler A, Gschwandtner U, Aston J, Borgwardt S, Drewe $\mathrm{M}$, Fuhr P, et al. The Basel early-detection-of-psychosis (FEPSY)study--design and preliminary results. Acta Psychiatr Scand 2007; 115(2): 114-25.

[65] Riecher-Rossler A, Gschwandtner U, Borgwardt S, Aston J, Pfluger M, Rossler W. Early detection and treatment of schizophrenia: how early? Acta Psychiatr Scand Suppl 2006(429): 73-80.

[66] Fusar-Poli P, Perez J, Broome M, Borgwardt S, Placentino A, Caverzasi $\mathrm{E}$, et al. Neurofunctional correlates of vulnerability to psychosis: a systematic review and meta-analysis. Neurosci Biobehav Rev 2007; 31(4): 465-84.

[67] Heydebrand G, Weiser M, Rabinowitz J, Hoff AL, DeLisi LE, Csernansky JG. Correlates of cognitive deficits in first episode schizophrenia. Schizophr Res 2004; 68(1): 1-9.

[68] Baare WF, van Oel CJ, Hulshoff Pol HE, Schnack HG, Durston S, Sitskoorn MM, et al. Volumes of brain structures in twins discordant for schizophrenia. Arch Gen Psychiatry 2001; 58(1): 33-40.

[69] Boos HB, Aleman A, Cahn W, Hulshoff Pol H, Kahn RS. Brain volumes in relatives of patients with schizophrenia: a metaanalysis. Arch Gen Psychiatry 2007; 64(3): 297-304.

[70] Borgwardt SJ, McGuire P, Fusar-Poli P, Radue EW, RiecherRossler A. Anterior cingulate pathology in the prodromal stage of schizophrenia. Neuroimage 2008; 39(2): 553-4.

[71] Borgwardt SJ, McGuire PK, Aston J, Berger G, Dazzan P, Gschwandtner U, et al. Structural brain abnormalities in individuals with an at-risk mental state who later develop psychosis. Br J Psychiatry Suppl 2007; 51: s69-75.

[72] Borgwardt SJ, Radue EW, Gotz K, Aston J, Drewe M, Gschwandtner $\mathrm{U}$, et al. Radiological findings in individuals at high risk of psychosis. J Neurol Neurosurg Psychiatry 2006; 77(2): 22933.

[73] Borgwardt SJ, Riecher-Rossler A, Dazzan P, Chitnis X, Aston J, Drewe $\mathrm{M}$, et al. Regional gray matter volume abnormalities in the at risk mental state. Biol Psychiatry 2007; 61(10): 1148-56. 
[74] Cannon TD, Thompson PM, van Erp TG, Toga AW, Poutanen VP, Huttunen $\mathrm{M}$, et al. Cortex mapping reveals regionally specific patterns of genetic and disease-specific gray-matter deficits in twins discordant for schizophrenia. Proc Natl Acad Sci USA 2002; 99(5): 3228-33.

[75] Haller S, Borgwardt SJ, Schindler C, Aston J, Radue EW, RiecherRossler A. Can cortical thickness asymmetry analysis contribute to detection of at-risk mental state and first-episode psychosis? A pilot study. Radiology 2009; 250(1): 212-21.

[76] Hulshoff Pol HE, Brans RG, van Haren NE, Schnack HG, Langen $\mathrm{M}$, Baare WF, et al. Gray and white matter volume abnormalities in monozygotic and same-gender dizygotic twins discordant for schizophrenia. Biol Psychiatry 2004; 55(2): 126-30.

[77] Keshavan MS, Montrose DM, Pierri JN, Dick EL, Rosenberg D, Talagala L, et al. Magnetic resonance imaging and spectroscopy in offspring at risk for schizophrenia: preliminary studies. Prog Neuropsychopharmacol Biol Psychiatry 1997; 21(8): 1285-95.

[78] Meisenzahl EM, Koutsouleris N, Bottlender R, Scheuerecker J, Jager M, Teipel SJ, et al. Structural brain alterations at different stages of schizophrenia: A voxel-based morphometric study. Schizophr Res 2008; 104(1-3): 44-60.

[79] Pantelis C, Velakoulis D, McGorry PD, Wood SJ, Suckling J, Phillips LJ, et al. Neuroanatomical abnormalities before and after onset of psychosis: a cross-sectional and longitudinal MRI comparison. Lancet 2003; 361(9354): 281-8.

[80] Seidman LJ, Faraone SV, Goldstein JM, Goodman JM, Kremen WS, Toomey R, et al. Thalamic and amygdala-hippocampal volume reductions in first-degree relatives of patients with schizophrenia: an MRI-based morphometric analysis. Biol Psychiatry 1999; 46(7): 941-54

[81] Borgwardt SJ, McGuire PK, Aston J, Gschwandtner U, Pfluger MO, Stieglitz RD, et al. Reductions in frontal, temporal and parietal volume associated with the onset of psychosis. Schizophr Res 2008; 106(2-3): 108-14

[82] Job DE, Whalley HC, Johnstone EC, Lawrie SM. Grey matter changes over time in high risk subjects developing schizophrenia. Neuroimage 2005; 25(4): 1023-30.

[83] Wright AM, Bempong J, Kirby ML, Barlow RL, Bloomquist JR. Effects of haloperidol metabolites on neurotransmitter uptake and release: possible role in neurotoxicity and tardive dyskinesia. Brain Res 1998; 788(1-2): 215-22.

[84] Konopaske GT, Dorph-Petersen KA, Sweet RA, Pierri JN, Zhang W, Sampson AR, et al. Effect of chronic antipsychotic exposure on astrocyte and oligodendrocyte numbers in macaque monkeys. Biol Psychiatry 2008; 63(8): 759-65.

[85] Wang HD, Dunnavant FD, Jarman T, Deutch AY. Effects of antipsychotic drugs on neurogenesis in the forebrain of the adult rat. Neuropsychopharmacology 2004; 29(7): 1230-8.
[86] Chlan-Fourney J, Ashe P, Nylen K, Juorio AV, Li XM. Differential regulation of hippocampal BDNF mRNA by typical and atypical antipsychotic administration. Brain Res 2002; 954(1): 11-20.

[87] Marx CE, VanDoren MJ, Duncan GE, Lieberman JA, Morrow AL. Olanzapine and clozapine increase the GABAergic neuroactive steroid allopregnanolone in rodents. Neuropsychopharmacology 2003; 28(1): 1-13.

[88] Parikh V, Khan MM, Terry A, Mahadik SP. Differential effects of typical and atypical antipsychotics on nerve growth factor and choline acetyltransferase expression in the cortex and nucleus basalis of rats. J Psychiatr Res 2004; 38(5): 521-9.

[89] Selemon LD, Lidow MS, Goldman-Rakic PS. Increased volume and glial density in primate prefrontal cortex associated with chronic antipsychotic drug exposure. Biol Psychiatry 1999; 46(2): 161-72.

[90] Bartzokis G, Nuechterlein KH, Lu PH, Gitlin M, Rogers S, Mintz J. Dysregulated brain development in adult men with schizophrenia: a magnetic resonance imaging study. Biol Psychiatry 2003; 53(5): 412-21.

[91] Hof PR, Haroutunian V, Friedrich VL, Jr., Byne W, Buitron C, Perl $\mathrm{DP}$, et al. Loss and altered spatial distribution of oligodendrocytes in the superior frontal gyrus in schizophrenia. Biol Psychiatry 2003; 53(12): 1075-85.

[92] Good CD, Johnsrude IS, Ashburner J, Henson RN, Friston KJ, Frackowiak RS. A voxel-based morphometric study of ageing in 465 normal adult human brains. Neuroimage 2001; 14(1 Pt 1): 21 36.

[93] Ashburner J, Friston KJ. Voxel-based morphometry--the methods. Neuroimage 2000; 11(6 Pt 1): 805-21.

[94] McGlashan TH, Hoffman RE. Schizophrenia as a disorder of developmentally reduced synaptic connectivity. Arch Gen Psychiatry 2000; 57(7): 637-48

[95] Glantz LA, Gilmore JH, Lieberman JA, Jarskog LF. Apoptotic mechanisms and the synaptic pathology of schizophrenia. Schizophr Res 2006; 81(1): 47-63.

[96] Reinke A, Martins MR, Lima MS, Moreira JC, Dal-Pizzol F, Quevedo J. Haloperidol and clozapine, but not olanzapine, induces oxidative stress in rat brain. Neurosci Lett 2004; 372(1-2): 157-60.

[97] Cunha, RA, Ferre S, Vaugeois JM, Chen JF. Potential therapeutic interest of adenosine $\mathrm{A} 2 \mathrm{~A}$ receptors in psychiatric disorders. Curr Pharm Des 2008; 14(15): 1512-24.

[98] Muller N, Schwarz MJ. COX-2 inhibition in schizophrenia and major depression. Curr Pharm Des 2008; 14(14): 1452-65.

[99] Pickar D, Vinik J, Bartko JJ. Pharmacotherapy of schizophrenic patients: preponderance of off-label drug use. PLoS ONE 2008; 3(9): e3150. 